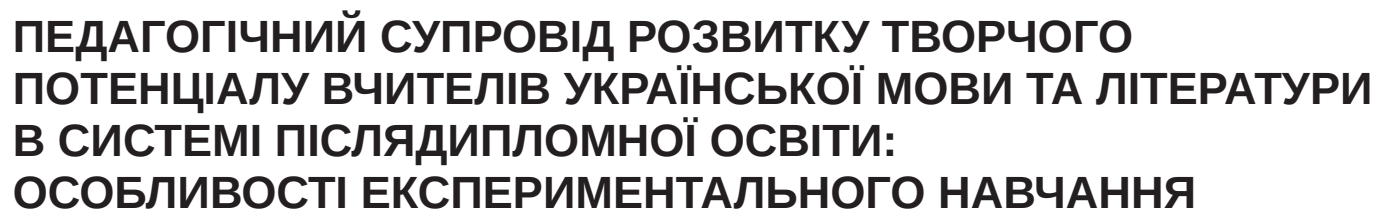

\title{
DEVELOPMENT OF UKRAINIAN LANGUAGE AND LITERATURE TEACHERS' CREATIVE POTENTIAL IN THE SYSTEM OF POST-GRADUATE EDUCATION: KEY FEATURES OF PEDAGOGICAL SUPPORT IN EXPERIMENTAL TRAINING
}

Принцип безперервної освіти навчання протягом життя є одним із провідних положень Національної стратегії розвитку освіти в Україні, оскільки лише креативний і морально розвинений учитель може виховати інновачійну, творчу особистість. На наш погляд, для підвищення ефективності навчального процесу в перепідготовиі вчителів-срілологів $є$ постійне оновлення та пошук нових, більш ефективних і сучасних форм і методів розвитку творчого потенціалу педагогів як у курсовий (два тижні) так і міжкурсовий (п'ять років) періоди.

Теоретичне та практичне навчання є органічним складником післядипломної освіти, у якій теоретичне навчання перебирає на себе функцію розвитку мислення педагога, збагачення й формування понятійного апарату, орієнтира в інформаційному розмаїmmі, прогностичну функцію, створення базису для аналізу й осмислення педагогічного досвіду, вироблення та здобуття нового знання. У закладах післядипломно освіти здійснюється постійне збагачення педагогів надбаннями науки, культури й інноваційними технологіями шляхом колективних та індивідуальних форм роботи, які стимулюють динаміку їхнього мислення.

Не менш важливий у системі післядипломної педагогічної освіти є міжкурсовий період навчання педагогів фрілологічних дисциплін, адже профресійне зростання і творчий розвиток не припиняються, педагоги повинні самі визначати свої потреби в навчанні впродовж життя, тому вміння керувати власним процесом навчання в чей період $i \epsilon$ запорукою розвитку та постійного самовдосконалення.

У статmі обгрунтовано й проаналізовано особливості змісту та фрорм розвитку творчого потенціалу вчителів української мови та літератури в системі післядипломної педагогічної освіти. Розкрито особливості навчання педагогів у курсовий і міжкурсовий періоди й ефективні способи та методи активізації їхнього творчого потениіалу. Автором розроблено авторський курс щодо активізації й розвитку потенційних можливостей учителів і тренінг емоційної грамотності з метою профрілактики та подолання емоційного й професійного вигорання педагогів.

Саме система післядипломної педагогіч ної освіти пробуджує іскру педагогічної творчості, сприяє орормуванню цілісно креативної особистості вчителів української мови та літератури в системі післядипломної педагогічної освіти, які здатні створити свою «Я-концепцію», здатні до суб'єкт-суб'єктної організації й самоорганізації освітнього та культурологічного простору. Зв'язок між курсовим і міжкурсовим періодами має особливо доповнюватися самоосвітою педагога, без якої немож- ливе професійне вдосконалення і творчий розвиток.

Ключові слова: творчий потенціал, учителі української мови та літератури, післядипломна педагогічна освіта, курсовий і міжкурсовий періоди навчання.

The principle of continuous lifelong learning is one of the guiding principles of the National Strategy for the Development of Education in Ukraine, since only a creative and morally intelligent teacher can bring up an innovative, creative personality. In our opinion, efficient educational process of training teachers- philologists involves constant update and search for new, more effective and modern forms and methods of developing teachers' creativity. It should be done both during the course training, which lasts for two weeks, and in inter-course five-year period The article substantiates and analyses the key features of content and forms creative potential of Ukrainian language and literature teachers in the system of postgraduate pedagogical education. The peculiarities of teachers' training in the course and inter-course period, effective ways and methods of activating their creative potential are demonstrated. The author has developed an experimental course on activating and developing teachers' potential and training emotional literacy in order to prevent and overcome emotional and professional burnout of teachers.

The system of postgraduate pedagogical education in the inter-course period is of no less importance. Professional growth and creative development should be continuous, teachers should outline their own needs for lifelong learning, as the ability to manage their own learning process during this period is the key to self-improvement. Therefore, the development and enhancement of individual creative potential of teachers-philologists in this course is realised with such effective traditional practices and forms of distant learning as: thematic laboratories and creative initiative groups, trainings on pedagogical reflection, face-to-face and virtual creative workshops, practical webinars, Internet conferences. In this process virtual communication techniques stimulate creative incentive and development of creative potential of teachers.

It is the system of postgraduate pedagogical education that encourages pedagogical creativity, contributes to the formation of a holistic creative personality of Ukrainian language and literature teachers. Thus, postgraduates are capable of creating their "Ego-conception", they become more self-organised and are efficient in educational and cultural space arrangement. The link between the course and the inter-course periods should be supported by teachers' self-education, which is seen as an essential component of professional creative development.

Key words: creative potential, teachers of Ukrainian language and literature, postgraduate pedagogical education, course and inter-course periods of study. 
Постановка проблеми в загальному вигляді. Основне завдання сьогодення, зокрема, професійної школи - навчити молоде покоління максимально використовувати свій природний потенціал. Навчити цього спроможний лише той педагог, який розкрив у собі творчий потенціал, який вдало користується цим потенціалом, який володіє мистецтвом викладання і $€$ педагогом-майстром.

Принцип безперервної освіти навчання протягом життя $є$ одним із провідних положень Національної стратегії розвитку освіти в Україні, оскільки лише креативний і морально розвинений учитель може виховати інноваційну, творчу особистість. На наш погляд, для підвищення ефективності навчального процесу в перепідготовці вчителівфрілологів $є$ постійне оновлення та пошук нових, більш еорективних і сучасних фрорм і методів розвитку творчого потенціалу педагогів як у курсовий (два тижні) так і міжкурсовий (п'ять років) періоди.

Аналіз останніх досліджень і публікацій. Творчість як шлях становлення профеесійного виявлення педагога розкрито в дослідженнях і наукових працях таких психологів і педагогів, як В.А. Андрєєв, О.В. Брушлинський, Л.С. Виготський, І.І. Драч, В.І. Загвязинський, І.А. Зазюн, В.О. Кан-Калик, В.В. Краєвський, Н.В. Кузьміна, О.М. Матюшкін, К.К. Платонов, Я.О. Пономарьов, С.О. Сисоєва.

На невіддільності педагогічної творчості від педагогічної майстерності вчителів української мови та літератури в післядипломній педагогічній діяльності наголошують такі вчені, як Н.Й. Волошина, В.А. Кан-Калик, В.І. Хазан, О.М. Куцевол, Т.В. Нікішина, Б.І. Степанишин.

Вчені одностайні в тому, що «творчість $є$ найвищим проявом феномена людини» [3, с. 118], що «сьогодення сприяє розвитку особистості педагога, оскільки активно спонукає до професіоналізму як одного зі способів виявлення власних потенційних можливостей» [1, с. 74].

3 огляду на вищезазначене, виникла необхідність визначити особливості організації фрорм і методів розвитку творчого потенціалу вчителів фрілологічної спеціальності в період підвищення кваліфрікації в системі післядипломної педагогічної освіти (далі - ППО) в рамках авторського експериментального навчання, що й визначило мету статті.

Завданням дослідження є аналіз особливостей змісту й фрорм розвитку творчого потенціалу вчителів української мови та літератури в системі ППО; розкрити особливості навчання педагогів у курсовий і міжкурсовий періоди (еоективні способи й методи активізації їхнього творчого потенціалу); розроблення авторського курсу щодо активізації та розвитку потенційних можливостей учителів і тренінгу емоційної грамотності 3 метою профрілактики й подолання емоційного та професійного вигорання педагогів.
3 творчістю пов'язані навчання й розвиток особистості: розвивається той, хто виходить за межі вже відомого, адже «творча людина - зрячий серед сліпих. Коли вона відкриває задачу (нерозгадану таємницю) і відчує її гострі кути, то вона вже знає, куди йти й над чим працювати, бачить те, що не бачать і не відчувають інші» [2, с. 13].

Виклад основного матеріалу. Розвиток творчого потенціалу фрахівця-словесника - це безперервний рух уперед, робота над собою, духовне та професійне зростання, самореалізація, тому система післядипломної педагогічної освіти є найзначнішою та найдовшою ланкою в неперервній освіті педагога. Для нас важливо через поєднання відповідних фрорм і методів навчання, яке має свої особливості, виражені в поєднанні теоретичної та практичної підготовки, забезпечити налаштування вчителів до творчої діяльності в курсовий і міжкурсовий періоди й системі ППО.

Відповідно до цього, процес саморозвитку має послідовні етапи організації навчання педагогів, які взаємопов'язані й містять діагностичний етап, мотиваційний, етап планування та створення умов для навчання, сам процес навчання, аналіз і самооцінювання власного творчого потенціалу, корекцію самого процесу навчання.

Як відомо, процес навчання в ППО відбувається в суб'єкт-суб'єктній взаємодії, тому той, хто навчається, має чітке уявлення про структуру навчальної діяльності, у якій бере активну участь, від розуміння й усвідомлення ії мети та мотивів і до отримання здобутків реальної творчої педагогічної діяльності й сфрормованості стійкої здатності до сомооцінювання, корегування на основі реорлексії. Отже, суб'єктна характеристика тих, хто навчається, поєднує організаційно-цільовий, змістово-процесуальний, діагностичний, результативний компоненти управління розвитком творчого потенціалу вчителів української мови та літератури в системі ППО [7].

Оскільки метою ППО є навчання вчителя впродовж життя, то в цій роботі потрібно прагнути до залучення педагогів у таку діяльність, яка найбільшою мірою наближена до творчої, де вправи, тренінги й заняття мають бути «спрямовані на управління розвитком особистості вчителя та активізацію його творчості» [9, с. 37].

Запропонований нами підхід до навчання вчителів-словесників у системі ППО вимагає максимально позитивного налаштування, відкритості в навчанні, виробленні індивідуально-оптимального стилю своєї діяльності, здатності до самопрогнозування та самоцінювання, переорієнтації від особистих рефлексивних властивостей, до творчості й педагогічної ресрлексії.

Варто зауважити, що для досягнення таких підходів необхідне створення певних організаційнопедагогічних умов розвитку творчого потенціалу, 
у контексті дослідження таким умовами $є$ наявність мотиваційних установок у процесі розвитку творчого потенціалу вчителів української мови та літератури в системі ППО, створення креативного середовища як умови активізації комунікативного потенціалу особистості вчителя, гармонійне духовне зростання педагога через мотивацію свого внутрішнього саморозвитку [6].

Динаміка розвитку суспільства, специфріка діяльності педагогів і потреби особистого досвіду зумовлюють процес систематичного оновлення профресійної компетентності освітян, який є спеціально організований і цілеспрямований. У період курсової перепідготовки вчителів-орілологів процес навчання потребує пошуку шляхів реалізації головної мети післядипломної освіти, яка реалізується в удосконаленні їхньої профресійної компетентності, забезпеченні фрахового зростання, розвитку педагогічної майстерності й власного творчого потенціалу. Опираючись на дослідження автора щодо структури творчого потенціалу вчителів української мови та літератури в системі ППО, визначаємо, що в курсовий і міжкурсовий періоди навчання в ППО ми насамперед:

- фрормуємо пізнавальну мотивацію вчителів-фрілологів і, як результат, творчих здібностей, потреб, нахилів, допитливості, задатків, інтересів, а найголовніше, потягу до створення чогось нового;

- розвиваємо можливості до перетворювальної діяльності, яка виражається в оригінальності, гнучкості, адаптивності, швидкості й оперативності мислення;

- орормуємо та розвиваємо позитивне налаштування на творчий процес, яке характеризує емоційний супровід творчості, емоційне налаштування на творчий процес, що висвітлює емоційнообразні характеристики психіки;

- розвиваємо самопізнання, самовираження, саморегуляцію, самоорганізацію, самоконтроль і самоствердження, що характеризує здатність учителя до саморегуляції та самоконтролю, якості уваги, самостійності, до вольового напруження, спрямованість педагога на досягнення кінцевої мети творчої діяльності, вимогливість до результатів власної творчості, внутрішнє прагнення до постійного розвитку й самовдосконалення [8].

Для забезпечення вчителів української мови та літератури таким творчим зростанням і перервного підвищення їхньої кваліфрікації під час курсової перепідготовки в системі післядипломної педагогічної освіти впроваджено спецкурс «Розвиток творчого потенціалу вчителів української мови і літератури» (6 год.). Специфрікою цього курсу $€$ те, що першим проводилося семінарське заняття (а не лекція) з теми «Самоаналіз творчої діяльності». Мета такої нетрадиційної структури курсу полягає в тому, щоб на перших етапах виявити в педагогів фрілологічних дисциплін рівень сорормованості знань про творчість загалом, творчі процеси і творчу діяльність, щоб з'ясувати рівень творчого потенціалу й, найголовніше, мотивувати педагогів на подальший розвиток творчого процесу в навчанні. Оскільки чим більше вчитель знає про творчість і творчі процеси, тим більше сам стає творчою людиною, а, знаючи методи, орієнтуючись у методах стимулювання власного творчого потенціалу й упроваджуючи їх у практику з колегами та учнями, автоматично стає зразком для останніх і має певний педагогічний вплив.

Важливо було також на перших етапах спілкування з педагогами вивчити потенційні можливості й потреби вчителів-срілологів засобами тестування та анкетування з психології, теорії, методики викладання предмета, щоб визначити рівень творчої активності кожного й надалі спланувати роботу з ними.

Теоретичне та практичне навчання $€$ органічним складником післядипломної освіти, у якій теоретичне навчання перебирає на себе фрункцію розвитку мислення педагога, збагачення та орормування понятійного апарату, орієнтира в інорормаційному розмаїтті, прогностичну фрункцію, створення базису для аналізу й осмислення педагогічного досвіду, вироблення та здобуття нового знання. У результаті цього зміст і структура теоретичного навчання детермінована гуманітаризацією змісту й цілями системи ППО, рівнем кваліфрікації вчителів, структурою об'єкта вивчення й об'єкта діяльності.

Отже, основні складники, які входять до системи післядипломної педагогічної освіти вчителів української мови та літератури, визначаємо такі:

- курсовий - період навчання в закладах педагогічної освіти;

- міжкурсовий - науково-методична робота (методичний супровід педагога);

- самоосвітня робота вчителя-фрілолога.

У закладах післядипломної освіти здійснюється постійне збагачення педагогів надбаннями науки, культури й інноваційними технологіями шляхом колективних та індивідуальних фрорм роботи, які стимулюють динаміку їхнього мислення.

Аналіз, практичний досвід автора й вивчення досвіду роботи ІПОПП показують, що найефективнішими та найпоширенішими в сучасній системі післядипломної освіти є такі інноваційні підходи, як тренінгово-проєктні методики, інтерактивні фрорми роботи, упровадження медіа- й інфрормаційної грамотності, гейміфікація.

Ретельно дібрані активні форми роботи також сприяють виявленню та розвитку творчого потенціалу і свободи, оригінального педагогічного стилю та самобутності, а саме: квести, рольові, імітаційні та ділові ігри, застосування коуч-методик і проведення коучинг-занять, адже «важлива роль того, 
хто навчається, у процесі свого навчання буде визначити основну тенденцію розвитку всіх сорер освіти дорослих - визволення того, хто навчається, від жорстких рамок системи освіти, перетворення тих, хто навчається, у самостійних організаторів свого навчання» [5, с. 74].

Відомо, що педагогічна профресія є профресією творчою, тому через високе емоційне напруження та специфріку профресії «педагог» надзвичайно корисним у діапазоні дослідження було проведення тренінгу емоційної грамотності «Профрілактика емоційного вигорання», який мав на меті вивчення рівня знань учителів української мови та літератури понять «емоційне вигорання», «стрес», «депресія», «методи психологічного захисту», набуття навичок збереження власного психологічного здоров'я, а, найголовніше, профілактику та запобігання виникненню синдрому емоційного вигорання вчителів-фрілологів. Учасники тренінгу активно долучилися й розглядали такі важливі питання: 1. Вплив емоційного здоров'я на педагогічну діяльність і власне життя. 2. Складники емоційної грамотності педагога. 3. Способи саморегуляції в стресових ситуаціях. 4. Просрілактика та подолання емоційного вигорання. 5. Конфлікти й способи поведінки в них. 6. Методи психологічного захисту і зняття психоемоційного напруження.

Участь в інтерактивних вправах сприяла в допомозі педагогам в усвідомленні індивідуальних і соціально-психологічних передумов і причин виникнення синдрому емоційного вигорання; дала можливість навчитися грамотно виявляти свої емоції, опановувати прийоми психологічного захисту, відновлення та просрілактики власної психічної енергії. Після закінчення тренінгу спостерігалися позитивні зміни в окремо взятому педагогічному колективі: емоційна розкутість і позитивний психологічний клімат між учасниками тренінгу (покращення взаємин, атмосфера задоволеності й доброзичливості); значне зниження тривожності, підвищення самооцінки й упевненості в собі; педагоги-фрілологи набули навичок саморегуляції, стали більш емоційно грамотними та стійкими до негативних впливів.

Не менш важливий у системі післядипломної педагогічної освіти $€$ міжкурсовий період навчання педагогів фрілологічних дисциплін, адже професійне зростання і творчий розвиток не припиняються, педагоги повинні самі визначати свої потреби в навчанні впродовж життя, тому вміння керувати власним процесом навчання в цей період і є запорукою розвитку та постійного самовдосконалення. Тому розвитку й посиленню індивідуального творчого потенціалу вчителів-фрілологів у міжкурсовий період сприяють такі ефективні традиційні й дистанційні формами роботи, як участь у роботах проблемних лабораторій і творчих ініціативних групах, тренінгах педагогічної рефрлексії, віртуальних авторських творчих майстернях і майстер-класах, участь у науково-практичних вебсемінарах і вебінарах, інтернет-конференціях, адже сам фракт залучення віртуальних засобів комунікації більшою мірою стимулює креативний процес і розвиток творчого потенціалу педагогів. У міжкурсовий період доцільно провести 3 педагогами тренінг креативності, який розробила Н. Хрящева [4]. У результаті проведення тренінгу педагоги мають усвідомити й подолати бар'єри до прояву творчості, усвідомити характеристики творчого середовища, опанувати навички й уміння керування творчим процесом.

На наше переконання, тільки диференційований підхід може домінувати в організації саморозвитку вчителів-словесників у системі ППО, адже вчитель створює індивідуальну програму особистісного та професійного зростання залежно від віку, кваліфікації, стажу, профресійної діяльності педагога, його освітніх та індивідуальних потреб.

Висновки. Підсумовуючи отримані результати, можемо сказати, що саме система післядипломної педагогічної освіти пробуджує іскру педагогічної творчості, сприяє фрормуванню цілісної креативної особистості вчителів української мови та літератури в системі післядипломної педагогічної освіти, які здатні створити свою «я-концепцію», здатні до суб'єкт-суб'єктної організації й самоорганізації освітнього та культурологічного простору.

Отже, у результаті дослідження визначено особливості змісту й фрорм розвитку творчого потенціалу вчителів української мови та літератури в системі ППО. Розкрито особливості навчання педагогів у курсовий і міжкурсовий періоди й есрективні способи та методи активізації їхнього творчого потенціалу. Автором продемонстровано авторський курс щодо активізації й розвитку потенційних можливостей учителів і тренінг емоційної грамотності 3 метою профілактики та подолання емоційного й профресійного вигорання педагогів.

Оскільки визначено технологічні особливості розвитку творчого потенціалу вчителів-словесників у трьох галузях післядипломної педагогічної освіти (інституційному, регіональному, об'єктному), то зв'язок між курсовим і міжкурсовим періодами має особливо доповнюватися самоосвітою педагога, без якої неможливе професійне вдосконалення й творчий розвиток. Перспективи подальших наукових розвідок убачаємо у вивченні реорлексивної діяльності вчителів фрілологічних спеціальностей і науково-методичного супроводу профресійного саморозвитку.

\section{БІБЛІОГРАФІЧНИЙ СПИСОК:}

1. Величко Л.П., Савчин М.М. Теоретичні і практичні аспекти педагогічної майстерності та методичної культури педагога. Педагогіка і психологія. 2013. № 4 (81). С. 74-81. 
2. Клименко В.В. Психологія творчості : навчальний посібник. Київ : Центр навчальної літератури, 2006. 408c.

3. Педагогіка вищої школи : підручник / за ред. Д.В. Чернілевського. Вінниця : АМСКП, Глобус-Прес, 2010. 408 C.

4. Психогимнастика в тренинге / под ред. Н.Ю. Хрящевой. Санкт-Петербург : Речь, Институт тренинга, 2002. 256 с.

5. Пуцов В. Освіта дорослих - важливий чинник розвитку особистості педагога. Післядипломна освіта в Україні. 2013. № 1. С. 73-74.

6. Сиваш С.В. Організаційно-педагогічні умови розвитку творчого потенціалу вчителів української мови і літератури в системі післядипломної педагогічної освіти. Науковий часопис національного педагогічного університету імені М.П. Драгоманова. Серія 5 «Педагогічні науки: реалії та перспективи» : збірник наукових праць / М-во освіти і науки України,
Нац. пед. ун-т імені М.П. Драгоманова. Вип. 71. Київ : Видавничий дім «Гельветика», 2019. С. 240-245.

7. Сиваш С.В. Структурно-фуункціональна модель розвитку творчого потенціалу вчителів української мови і літератури в системі післядипломної педагогічної освіти. Науковий вісник Льотної академії. Серія «Педагогічні науки» : збірник наукових праць / гол. ред. Т.С. Плачинда. Кропивницький : ЛА НАУ, 2020. Вип. 7. С. 96-100.

8. Сиваш С.В. Структурні компоненти творчого потенціалу вчителя української мови та літератури. Педагогіка формування творчої особистості у вищій і загальноосвітній школах : збірник наукових праць / за ред. Т.І. Сущенко. Запоріжжя : КПУ, 2016. Вип. 48 (101). с. 204-214.

9. Устинова Н. Технологічні особливості розвитку творчого потенціалу вчителя у системі післядипломної педагогічної освіти. Післядипломна освіта в Україні. 2008. № 1. С. 37-40. 